\title{
Study of the Correlation between Serum Testosterone Level and Sarcopenia in Egyptian Male Patients with Liver Cirrhosis
}

\author{
Atef Abo Alsood Ali ${ }^{1}$, Naglaa Said El Abd ${ }^{1}$, Shaimaa Abd El-Hamid \\ Abd El Mageed ${ }^{2}$, Mostafa Ibrahim Al Goghop ${ }^{3}$ \\ ${ }^{1}$ Tropical Medicine Dept., Faculty of Medicine, Menoufia University, Menoufia, Egypt \\ ${ }^{2}$ Diagnostic Radiology Dept., Faculty of Medicine, Menoufia University, Menoufia, Egypt \\ ${ }^{3}$ Hepatology Dept., Al haram Specialized Hospital, Cairo, Egypt
}

Corresponding Author Naglaa Said El-Abd

Mobile: 01092304322

\section{E mail:}

Naglaa_elabd@yahoo. com

Key words: Cirrhosis, Sarcopenia, Testosterone
Background and study aim: Irrespective of etiology, liver cirrhosis together with its complications can affect other body organs and lead to a great morbidity and mortality. In Cirrhotic patients, Sarcopenia block normal life activities. Low serum testosterone has been reported in up to $90 \%$ of men with liver cirrhosis. This study aimed to assess the correlation between serum testosterone level and sarcopenia in Egyptian male patients with liver cirrhosis.

Patients and Methods: This prospective study included sixty cirrhotic males. Three groups were designed according to Child-Pugh classification. Twenty healthy males were included as control group. Patients and controls were subjected to complete blood picture, liver and kidney functions. Serum total $\&$ free testosterone was analyzed by specific enzyme-linked immunosorbent assay (ELISA) kit and Skeletal Muscle Index (L3 SMI) was assessed by CT scan.
Results: There was significant decrease in serum levels of free and total testosterone in cirrhotic patients than controls, with lowest levels in child $\mathrm{C}$ cirrhotic males ( $\mathrm{p}$ value $<0.001) .32(53.3 \%)$ cirrhotic patients were sarcopenic. At cutoff point 14.1 $\mathrm{nmol} / \mathrm{L}$ total testosterone level has Sensitivity 91\%, Specificity $94 \%$ and Accuracy $93.0 \%$ to predict sarcopenia in cirrhotic males with $\mathrm{AUC}=0.938$. There was significant positive correlation between total testosterone level and the L3 SMI $(r=0.819, \mathrm{P}<0.001)$. In addition, a positive correlation was detected between total testosterone and hemoglobin $(\mathrm{r}=0.668, \mathrm{P}<0.001)$, serum $\mathrm{Na}(\mathrm{r}=0.846, \mathrm{P}<0.001)$ and Platelet count $(\mathrm{r}=0.904, \mathrm{P}<0.001)$, also negative correlation with MELD score $(r=-0.928, \mathrm{P}<0.001)$.

Conclusion: Significant positive correlation between total testosterone level and Skeletal Muscle Index (L3 SMI) and low testosterone level is associated with sarcopenia in cirrhotic males.

\section{INTRODUCTION}

Cirrhosis is a progressive chronic liver disease characterized by diffuse fibrosis, severe interruption of the intrahepatic venous flow and portal hypertension [1].

Clinical features of hypogonadism like gynecomastia, loss of libido and infertility are common in cirrhotic male patients [2]. In men with cirrhosis the more liver disease is severe the more testosterone levels decrease [3].

Sarcopenia, defined as muscle loss and dysfunction, is a common feature of all chronic inflammatory diseases and involves impairment of either the contractile, metabolic or endocrine functions of skeletal muscle [4].

Sarcopenia is an important diagnostic lineament of malnutrition, a clinical condition that is often challenging to objectively define in cirrhotic patients [5]. Sarcopenia is common in cirrhotic patients and block normal life activities. Muscle weakness limits exercise capability, can profoundly impact simple activities of daily living and may also contribute to fatigue. These effects impact participation in the community, family and workforce. They also suffer from muscle cramps which have been identified as a major factor affecting quality of life [6]. 
Lumbar vertebrae-3 skeletal muscle index (L3 SMI) was expressed as cross-sectional muscle area/height ${ }^{2}$. The cutoff for sarcopenia was based on the study of Prado et al., 2008 [7]. It has been shown to be of higher accuracy and the most commonly employed method in studies investigating sarcopenia in cirrhosis [8].

Testosterone deficiency has been identified as an independent prognostic marker in liver cirrhosis. In addition, many clinical sequelae of advanced liver disease, as anemia, bone disease, gynecomastia and sarcopenia are also found in hypogonadism. Therefore, low testosterone levels may contribute to at least some of these manifestations [9]. This study aimed to assess the correlation between serum testosterone level and sarcopenia in Egyptian male patients with liver cirrhosis.

\section{PATIENTS AND METHODS}

Sixty men with liver cirrhosis were selected from inpatient and outpatient clinic of Tropical Medicine Department, Menofia University Hospital and the Hepatology Department, Al haram Specialized Hospital in the period between June 2016 to December 2016. Their ages ranged from 33 to 57 years with a mean age of $46.5 \pm 6.53$ years. Twenty healthy men as a control group of matched age were incorporated in the study.

Two groups were designed including all participants: Group I: Included 60 patients with liver cirrhosis. They were subdivided according to child-Pugh classification into: Group Ia: included 20 patients with Child-A liver cirrhosis. Group Ib: included 20 patients with Child-B. Group Ic: included 20 patients with Child-C. Group II: included 20 healthy subjects as a control group. Patients aged more than70 years, immobilized patients, patients with diabetes mellitus, renal impairment, hypogonadism, cancer prostate, previous or ongoing malignant disease including HCC were excluded. Also patients receiving medications that influence androgen levels, such as high dose opiates, glucocorticoids, or antiepileptic, etc. and obese \& overweight patients were excluded from the study.

Approved by the local ethics committee of Tropical Medicine Department of Faculty of Medicine Menoufia University and Hepatology Department, Al haram Specialized Hospital; and informed consent was taken from each patient to provide a blood sample and to review the medical record for research purposes.
All patients and controls were subjected to proper and detailed history taking, general and local examination. Weight had two measures for assessment: objective scale weight $(\mathrm{kg})$ and subjective estimation of dry weight. Estimated dry weight $(\mathrm{kg})$ was calculated using scale weight minus ascites weight based upon severity (mild: $5 \%$; moderate: $10 \%$; severe: $15 \%$ ). And $5 \%$ was subtracted for bilateral pedal edema. Body mass index (BMI) was measured using estimated dry weight divided by height ${ }^{2}\left(\mathrm{~kg} / \mathrm{m}^{2}\right)$ [5].

Laboratory investigations: Complete blood count, fasting \& 2hour post-prandial blood sugar, serum sodium, liver and kidney function tests were performed for all patients and controls. MELD score was calculated for all cirrhotic patients. Serological tests for viral markers (HBs Ag and $\mathrm{HCV} \mathrm{Ab}$ by enzyme-linked immune sorbent assay and were confirmed by HCV RNA and HBV DNA by quantitative PCR. Serum free [10] \& total testosterone [11] levels were done by ELISA.

Radiological evaluation was in the form of abdominal ultrasonography to evaluate liver, spleen, portal vein, the amount of ascites and both kidneys. CT scan was done for Para spinal skeletal muscle at the level of the 3rd lumbar vertebral body (L3 SMI) [7]. The L3-L4 slice was selected for the quantitative analysis. Images were analyzed using a dedicated workstation (Leonardo Syngo; Siemens Medical System, Erlangen, Germany) that enabled specific tissue demarcation using thresholds of Hounsfield unit (HU) which was previously recorded. Skeletal muscle tissue was separated by using different density thresholds: using the density value from $+35 \mathrm{HU}$ to $+150 \mathrm{HU}$ was used to separate muscle tissue from fat and bone tissues [12]. By using a special computer software, cross-sectional areas $\left(\mathrm{cm}^{2}\right)=$ tissue pixels $\times$ the pixel surface area. The skeletal muscle area and intramuscular adipose tissue was normalized by divided on height ${ }^{2}$ $\left(\mathrm{cm}^{2} / \mathrm{m}^{2}\right)$. Sarcopenia was diagnosed if the $\mathrm{L} 3$ Skeletal Muscle Index (SMI) was $\leq 53 \mathrm{~cm}^{2} / \mathrm{m}^{2}$ for men with BMI $\geq 25$ and if SIM $\leq 43 \mathrm{~cm}^{2} / \mathrm{m}^{2}$ for men with $\mathrm{BMI}<25$ ) [13].

\section{Statistical Analysis}

Data was statistically analyzed using an IBM compatible personal computer with SPSS statistical package version 20 (SPSS Inc. Released 2011. IBM SPSS statistics for windows, version 20.0, Armnok, NY: IBM Corp.), and for all the analysis a $\mathrm{p}$ value $<0.05$ was considered statistically significant. 


\section{RESULTS}

A total of 60 males with liver cirrhosis and 20 healthy males as controls were enrolled in this study. Child A (GIa) were 20 males. Their ages ranged between 40 and 57 years with mean 49.40 years and BMI ranged between 18.7 and 23.6 $\mathrm{kg} / \mathrm{m}^{2}$. Child B (GIb) included 20 males. Their ages ranged between 36 and 56 years with mean 45.70 years and BMI ranged between 17.50 and $23.20 \mathrm{~kg} / \mathrm{m}^{2}$. Child C (GIc) included 20 males. Their ages ranged between 33 and 52 years with mean 44.40 years and BMI ranged between 17.1 and $23.4 \mathrm{~kg} / \mathrm{m}^{2}$. Controls (GII) were 20 males. Their ages ranged between 38 and 57 years with mean 46.80 years and BMI ranged between 18.9 and $24.9 \mathrm{~kg} / \mathrm{m}^{2}$. Age ( $\mathrm{p}$ value $<0.075$ ) given that the null hypothesis is true but statistical significance difference ( $\mathrm{p}$ value $<0.05$ ) between the studied groups regarding BMI (using estimated dry weight) Table (1).

In cirrhotic patients, HCV was the etiology of cirrhosis in $93.3 \%$ of patients and the rest was caused by HBV \& HCV co-infection. There was statistically significant difference between studied patients regarding history of hematemesis and/or melena, hepatic encephalopathy, edema of the lower limb, jaundice and muscle wasting, while there was no statistically significant difference as regard the presence of palmer erythema ( $\mathrm{p}$ value $<0.07$ ) and spider naevi ( $p$ value <0.153). Gynecomastia, feminine hair distribution and abdominal wall hernia were statistically differed among studied patients Table (1).

Regarding the free and total testosterone levels in all studied groups, there was significant decrease in cirrhotic patients than controls ( $p$ value $<0.001$ ). The mean value of free and total testosterone levels in controls (GII) $(3.54 \pm 0.86 \mathrm{ng} / \mathrm{mL} \&$ $18.68 \pm 2.69 \mathrm{nmol} / \mathrm{L}$ respectively) is higher when compared with Child A $(2.56 \pm 0.66 \mathrm{ng} / \mathrm{mL} \&$ $16.13 \pm 2.08 \mathrm{nmol} / \mathrm{L})$ and Child B (1.56 \pm 0.47 $\mathrm{ng} / \mathrm{mL} \& 13.72 \pm 2.51 \mathrm{nmol} / \mathrm{L}$ ) with the lowest levels in child-C cirrhotic patients $(0.75 \pm 0.15$ $\mathrm{ng} / \mathrm{mL} \& 6.21 \pm 2.38 \mathrm{nmol} / \mathrm{L}$ ) (Table 2).

In studied groups the L3 skeletal muscle index (SMI) was significantly different ( $p$ value $<0.001$ ). It was higher in controls $(44.6 \pm 0.79)$ than in cirrhotic patients Child A, B and C (43.3 \pm 0.66 , $42.4 \pm 0.89$ and $40.9 \pm 2.26$ respectively). The presence of sarcopenia was significantly different among studied groups. It was not detected in controls, and significantly increased with increasing child grade from child-A (15\%) to child-B (55\%) and highest in child-C (90\%) of cirrhotic males (Table 3).

Receiver operating curve to assess the best cut off point of total testosterone level to predict the presence of sarcopenia showed that at cutoff point $14.1 \mathrm{nmol} / \mathrm{L}$, total testosterone level has sensitivity $91 \%$, specificity $94 \%$ and accuracy $93.0 \%$ to predict the presence sarcopenia in cirrhotic males (Figure 1).

In cirrhotic males, serum total testosterone level showed high significant positive correlation with SMI ( $r=0.819$ and $p$ value $<0.001)$ (Figure 2).

There was a statistical high significant positive correlation between serum total testosterone level ( $\mathrm{p}$ value $<0.001$ ) with Body mass index, hemoglobin concentration, ALT, Serum albumin, serum Na \& Platelets. There was high significant negative correlation between total testosterone and MELD score, INR \& bilirubin in cirrhotic patients (Table 4 and Figure 3). Significant positive correlation (p value $<0.001$ ) was found between L3 SMI and Serum Na \& Platelets in cirrhotic males, and significant negative correlation ( $\mathrm{p}$ value $<0.001$ ) with MELD score (Table 4). 
Table (1): Demographic data \& General examination

\begin{tabular}{|c|c|c|c|c|c|c|}
\hline Studied variables & $\begin{array}{c}\text { GIa } \\
(\mathrm{N}=\mathbf{2 0})\end{array}$ & $\begin{array}{c}\text { GIb } \\
(\mathrm{N}=\mathbf{2 0}) \\
\end{array}$ & $\begin{array}{c}\text { GIc } \\
(\mathrm{N}=\mathbf{2 0})\end{array}$ & $\begin{array}{c}\text { GII } \\
(\mathrm{N}=\mathbf{2 0})\end{array}$ & Test & $\begin{array}{c}P \\
\text { value } \\
\end{array}$ \\
\hline Age $(-\mathrm{X} \pm \mathrm{SD})$ & $49.40 \pm 5.60$ & $45.70 \pm 6.87$ & $44.40 \pm 6.11$ & $46.80 \pm 5.91$ & $\mathrm{~F}(2.39)$ & 0.075 \\
\hline $\begin{array}{l}\text { BMI }(\mathrm{kg} / \mathrm{m} 2) \\
((X) \pm \mathrm{SD})\end{array}$ & $20.27 \pm 1.44$ & $20.00 \pm 2.11$ & $19.36 \pm 1.88$ & $21.68 \pm 1.78$ & $\mathrm{~F}(5.80)$ & 0.001 \\
\hline Hepatic encephalopathy & $0(0 \%)$ & $11(55 \%)$ & $19(95 \%)$ & & $\chi^{2}(43.33)$ & 0.001 \\
\hline Muscle wasting & $0(0 \%)$ & $9(45 \%)$ & $16(80 \%)$ & & $\chi^{2}(26.47)$ & 0.002 \\
\hline Gynecomastia & $0(0 \%)$ & $3(15 \%)$ & $7(35 \%)$ & & $\chi^{2}(8.88)$ & 0.012 \\
\hline $\begin{array}{l}\text { Feminine } \\
\text { hair distribution }\end{array}$ & $0(0 \%)$ & $9(45 \%)$ & $15(75 \%)$ & & $\chi^{2}(23.75)$ & 0.007 \\
\hline
\end{tabular}

( $\mathrm{X} \pm \mathrm{SD})$; mean \pm standard deviation, $\mathrm{F}$; ANOVA (analysis of variance) test of significance, $\chi^{2}$; chi square test, BMI; Body Mass Index.

Table (2): Biochemical investigations of studied groups

\begin{tabular}{|c|c|c|c|c|c|c|}
\hline \multirow[t]{2}{*}{ Studied variables } & $\begin{array}{c}\text { GIa } \\
(\mathbf{N}=\mathbf{2 0}) \\
\end{array}$ & $\begin{array}{c}\text { GIb } \\
(\mathbf{N}=\mathbf{2 0}) \\
\end{array}$ & $\begin{array}{c}\text { GIc } \\
(\mathrm{N}=\mathbf{2 0})\end{array}$ & $\begin{array}{c}\text { GII } \\
(\mathrm{N}=\mathbf{2 0}) \\
\end{array}$ & \multirow{2}{*}{$\begin{array}{c}\text { Test of } \\
\text { significance }\end{array}$} & \multirow{2}{*}{$\begin{array}{c}\mathbf{P} \\
\text { value }\end{array}$} \\
\hline & \pm SD $^{\overline{\mathrm{X}}}$ & $\pm \mathrm{SD}^{\overline{\mathrm{X}}}$ & $\pm \mathrm{SD}^{\overline{\mathrm{X}}}$ & $\pm \mathrm{SD}^{\overline{\mathrm{X}}}$ & & \\
\hline INR & $1.49 \pm 0.13$ & $1.80 \pm 0.22$ & $2.39 \pm 0.30$ & $0.94 \pm 0.1$ & $\overline{F(176.1)}$ & $<0.001$ \\
\hline $\begin{array}{l}\text { Serum albumin } \\
\text { (g/dl) }\end{array}$ & $3.65 \pm 0.15$ & $2.98 \pm 0.24$ & $2.28 \pm 0.39$ & $4.33 \pm 0.21$ & $\mathrm{~F}(222.51)$ & $<0.001$ \\
\hline $\begin{array}{ll}\text { Total } & \text { bilirubin } \\
(\mathrm{mg} / \mathrm{dl}) & \\
\end{array}$ & $0.94 \pm 0.17$ & $2.87 \pm 0.63$ & $3.76 \pm 0.39$ & $0.71 \pm 0.16$ & $F(622.56)$ & $<0.001$ \\
\hline $\begin{array}{ll}\begin{array}{l}\text { Serum } \\
(\mathrm{mmol} / \mathrm{L})\end{array} & \mathrm{Na} \\
\end{array}$ & $138.7 \pm 1.64$ & $129.20 \pm 3.30$ & $123.10 \pm 3.02$ & $139.40 \pm 1.60$ & $\mathrm{~F}(156.52)$ & $<0.001$ \\
\hline MELD score & $11.00 \pm 1.65$ & $14.20 \pm 2.28$ & $22.20 \pm 2.85$ & & $\mathrm{~F}(123.82)$ & $<0.001$ \\
\hline $\begin{array}{l}\text { Free testosterone } \\
(\mathrm{ng} / \mathrm{dl})\end{array}$ & $2.56 \pm 0.66$ & $1.56 \pm 0.47$ & $0.75 \pm 0.15$ & $3.54 \pm 0.86$ & $F(82.95)$ & $<0.001$ \\
\hline $\begin{array}{l}\text { Total testosterone } \\
(\mathrm{nmol} / \mathrm{L})\end{array}$ & $16.13 \pm 2.08$ & $13.72 \pm 2.51$ & $6.21 \pm 2.38$ & $18.68 \pm 2.69$ & F (98.09) & $<0.001$ \\
\hline
\end{tabular}

$(\mathrm{X} \pm \mathrm{SD})$; mean \pm standard deviation, F; ANOVA (analysis of variance) test of significance, INR; international normalized ratio, MELD; Model for End-Stage Liver Disease.

Table (3): L3 Skeletal muscle index (SMI) \& Sarcopenia in studied groups (No=80)

\begin{tabular}{|c|c|c|c|c|c|c|c|c|c|c|}
\hline \multirow{2}{*}{$\begin{array}{c}\text { Studied } \\
\text { variables }\end{array}$} & \multicolumn{2}{|c|}{$\begin{array}{c}\text { GIa } \\
(\mathbf{N}=20)\end{array}$} & \multicolumn{2}{|c|}{$\begin{array}{c}\text { GIb } \\
(\mathbf{N}=\mathbf{2 0})\end{array}$} & \multicolumn{2}{|c|}{$\begin{array}{c}\text { GIc } \\
(\mathbf{N}=\mathbf{2 0})\end{array}$} & \multicolumn{2}{|c|}{$\begin{array}{c}\text { GII } \\
(\mathbf{N}=20)\end{array}$} & \multirow{2}{*}{$\begin{array}{c}\text { Test of } \\
\text { significance }\end{array}$} & \multirow{2}{*}{$\begin{array}{c}\mathbf{P} \\
\text { value }\end{array}$} \\
\hline & \multicolumn{2}{|c|}{ \pm SD $\overline{\bar{X}}$} & \multicolumn{2}{|c|}{$\pm \mathrm{SD}^{\overline{\mathrm{X}}}$} & \multicolumn{2}{|c|}{$\pm \mathrm{SD}^{\overline{\mathrm{X}}}$} & \multicolumn{2}{|c|}{$\pm \mathrm{SD}^{\overline{\mathrm{X}}}$} & & \\
\hline $\begin{array}{c}\mathrm{SMI}\left(\mathrm{cm}^{2} / \mathrm{m}^{2}\right) \\
\text { range }\end{array}$ & \multicolumn{2}{|c|}{$\begin{array}{c}43.3 \pm 0.66 \\
41.8-43.9\end{array}$} & \multicolumn{2}{|c|}{$\begin{array}{l}42.4 \pm 0.89 \\
40.6-43.6\end{array}$} & \multicolumn{2}{|c|}{$\begin{array}{l}40.9 \pm 2.26 \\
37.8-44.6\end{array}$} & \multicolumn{2}{|c|}{$\begin{array}{c}44.6 \pm 0.79 \\
43.5-46.2\end{array}$} & $F(27.31)$ & $<0.001$ \\
\hline \multirow{2}{*}{ Sarcopenia } & No. & $\%$ & No. & $\%$ & No. & $\%$ & No. & $\%$ & \multirow{2}{*}{$\chi^{2}(41.25)$} & \multirow[b]{2}{*}{0.001} \\
\hline & 3 & 15 & 11 & 55 & 18 & 90 & 0 & 0 & & \\
\hline
\end{tabular}

$\overline{\mathrm{X}} \pm \mathbf{S D}$; mean \pm standard deviation, SMI; Skeletal muscle index, F; ANOVA (analysis of variance) test of significance, $\chi 2$; chi square test 


\begin{tabular}{|c|c|c|c|c|c|c|}
\hline $\begin{array}{c}\text { Cutoff point } \\
\text { of total } \\
\text { testosterone }\end{array}$ & AUC & Sensitivity & Specificity & Accuracy & $\begin{array}{c}\text { Positive } \\
\text { predictive } \\
\text { value (PPV) }\end{array}$ & $\begin{array}{c}\text { Negative } \\
\text { Predictive } \\
\text { value (NPV) }\end{array}$ \\
\hline $14.1 \mathrm{nmol} / \mathrm{L}$ & 0.938 & $91 \%$ & $94 \%$ & $93.0 \%$ & $91.0 \%$ & $94.0 \%$ \\
\hline
\end{tabular}

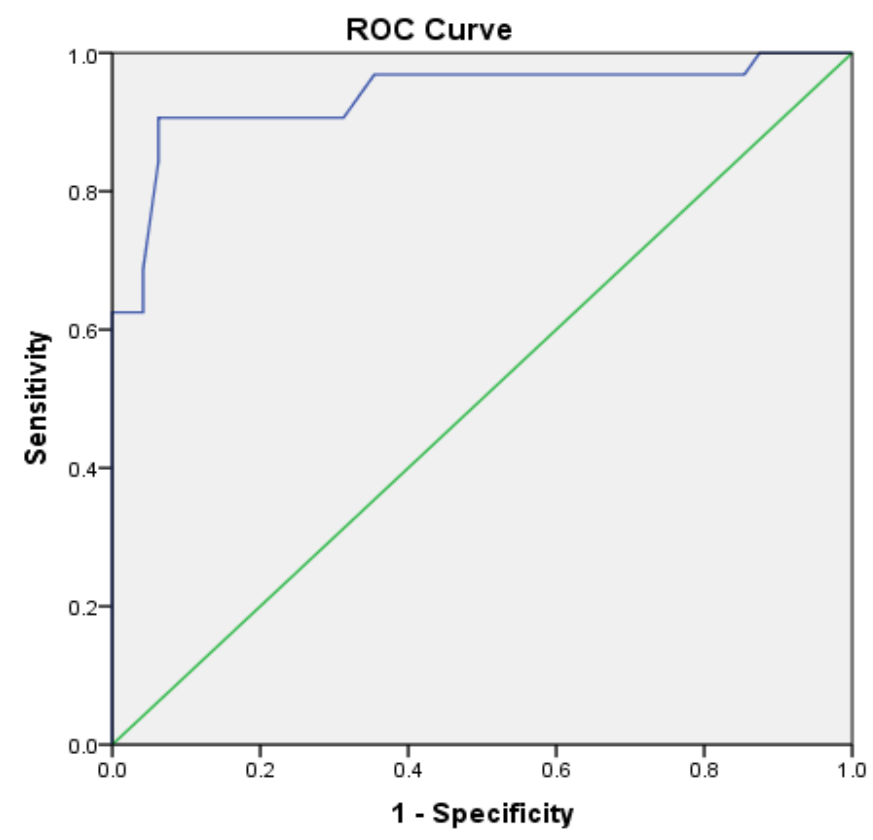

Diagonal segments are produced by ties.

Fig. (1) : ROC curve of total testosterone level to predict sarcopenia in cirrhotic males

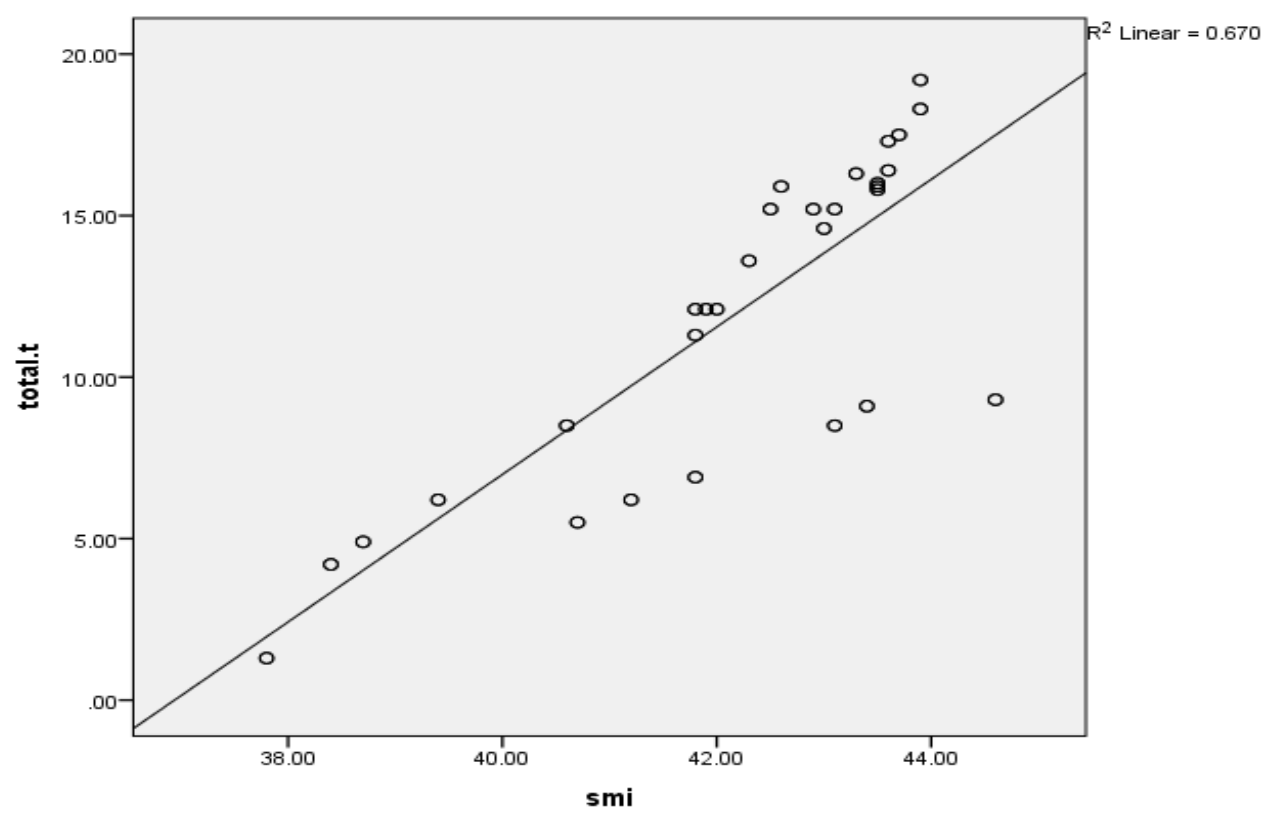

Fig. (2) : Correlation between total testosterone level and SMI in cirrhotic males 
Table (4): Correlation between total testosterone level \& SMI and other studied parameters among cirrhotic males

\begin{tabular}{|l|c|c|}
\hline \multirow{2}{*}{ Studied variables } & \multicolumn{2}{c|}{ Total testosterone level } \\
\cline { 2 - 3 } & 0.536 & p value \\
\hline BMI & 0.668 & $<0.001$ \\
\hline Hb & -0.928 & $<0.001$ \\
\hline MELD score & -0.853 & $<0.001$ \\
\hline INR & 0.848 & $<0.001$ \\
\hline ALT & 0.848 & $<0.001$ \\
\hline Serum albumin & -0.795 & $<0.001$ \\
\hline Total bilirubin & 0.846 & $<0.001$ \\
\hline Serum Na & 0.904 & $<0.001$ \\
\hline Platelet count & Skeletal muscle index (SMI) \\
\hline & -0.698 & $<0.001$ \\
\hline MELD score & 0.630 & $<0.001$ \\
\hline Serum Na & 0.705 & $<0.001$ \\
\hline Platelet count & \multicolumn{2}{|c|}{} \\
\hline
\end{tabular}

BMI; Body Mass Index, Hb; hemoglobin concentration, MELD; The Model for End-Stage Liver Disease, INR; international normalized ratio, ALT; alanine aminotransferase, Na; serum sodium.
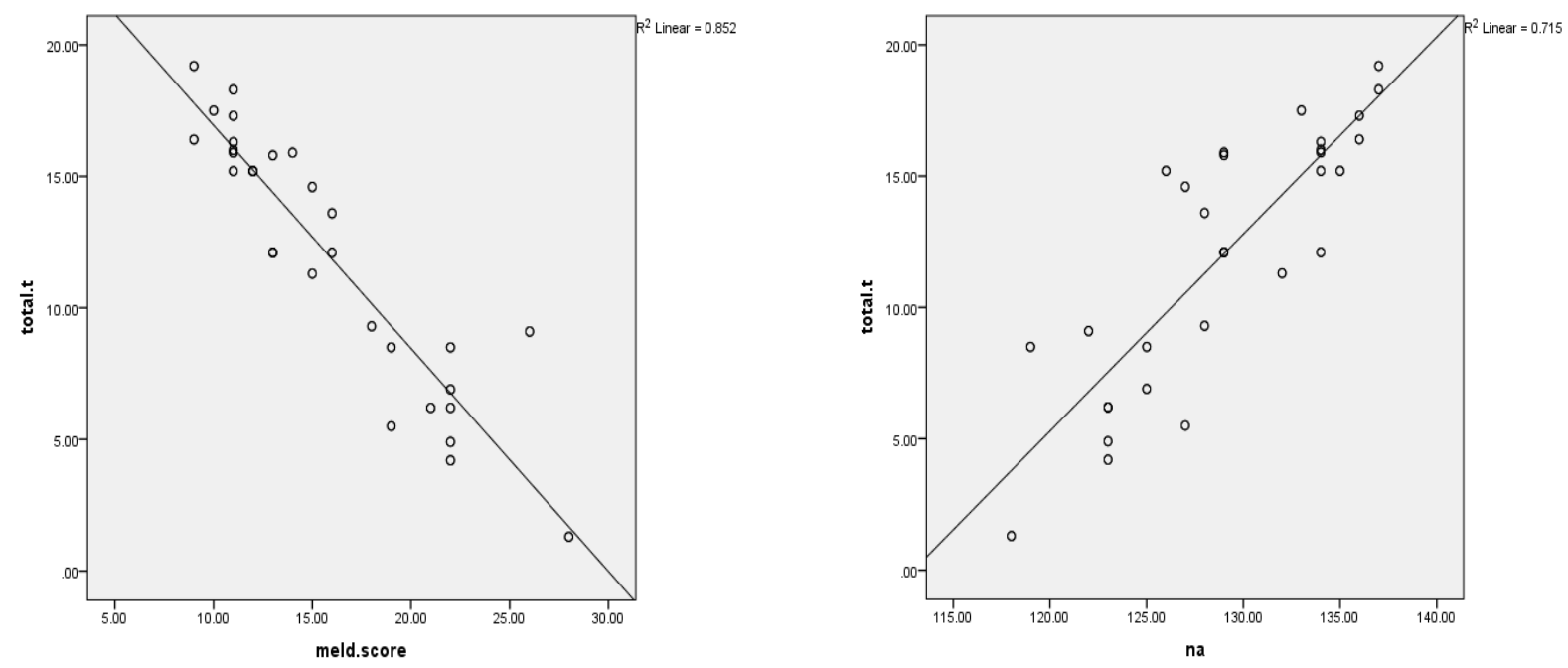

Fig. (3) (a\&b): Correlation between total testosterone level and MELD score \& serum sodium in cirrhotic males 


\section{DISCUSSION}

Cirrhosis is considered as an increasing cause of morbidity and mortality in developed countries [14]. Cirrhotic males have clinical features of hypogonadism including gynecomastia, loss of libido and infertility while females may experience amenorrhea or oligomenorrhea [15].

A decreased testosterone level has been detected in up to $90 \%$ of males with liver cirrhosis [16]. It is blamed to cause many of the clinical features of end stage liver disease in males, including altered body hair distribution, fatigue and impaired sexual function [17].

In this study there was significant difference ( $p$ value $<0.001$ ) between cirrhotic groups regarding feminine hair distribution. This agreed with Yee and Lidofsky [18] and also with De Bruyn and Graviss [19] who reported that examination of cirrhotic patients may show diminished or feminine distribution of body hair.

Our study revealed that there was statistical significant increase ( $p$ value $<0.001$ ) in both free and total testosterone levels in controls when compared with cirrhotic males. In addition there was significant decrease in free and total testosterone levels with increasing Child Pugh scores. These results agreed with Yurci et al. [20] who reported that in cirrhotic patients, low plasma testosterone levels was correlated with Child Pugh scores and express the severity of liver damage. Southren et al. [21] as well proved decreased plasma level and production rate of testosterone in cirrhotic males and that the mechanism is probably resulting from suppression of hypothalamic/pituitary function rather than testicular atrophy.

Sarcopenia is one of the commonest complications of cirrhosis and can contribute significantly to morbidity and mortality in patients with liver cirrhosis [22]. It is defined as a muscle mass two standard deviations below the healthy young adult mean. The L3 Skeletal Muscle Index (SMI) was expressed as cross-sectional muscle area/ height ${ }^{2}$ [23]. We measured BMI by using estimated dry weight divided by height ${ }^{2}(\mathrm{~kg} / \mathrm{m} 2)$ [5]. The calculated BMI for all cirrhotic males was $<25$, at the same time we selected the controls with BMI $<25$ so we used $\mathrm{L} 3 \mathrm{SMI} \leq 43 \mathrm{~cm} 2 / \mathrm{m} 2$ as a cut off for detection of sarcopenia. This cutoff was also used by krell et al. [24] based on a CTbased study in patients with solid tumors. In our study there was high statistical significant difference ( $\mathrm{p}$ value <0.001) among studied groups regarding SMI with the lowest level in child-C cirrhotic patients.

Sarcopenia was significantly different among studied groups in our study. It was not detected in control group, and significantly increased with increasing child grade from A to B and highest in child-C cirrhotic patients. The present study revealed that, sarcopenia was detected in $53.3 \%$ of cirrhotic patients (32 out of 60 patients). Cross-sectional imaging studies revealed that among patients with cirrhosis sarcopenia can be detected in 30\%-70\% [25].

Many factors were reported to contribute to development of sarcopenia in cirrhosis, including elevated inflammatory mediators, malnutrition, reduced insulin-like growth factor-1 [26] and breakdown of muscle protein for energy use because of low hepatic glycogen synthesis and storage [27].

In this research we found that at cutoff point 14.1 nmol/L, total testosterone has sensitivity $91 \%$, specificity $94 \%$ and accuracy $93 \%$ to predict sarcopenia in men with liver cirrhosis. Tandon et al. [28] has reported that male sarcopenic patients had lower total testosterone levels than non-sarcopenic patients $(15 \pm 1 \mathrm{nmol} / \mathrm{L}$ versus $22 \pm 1.2, \mathrm{P}=0.005)$ \& low testosterone levels (OR $0.95,95 \%$ CI $0.91-0.99, \mathrm{P}=0.02$ ) were associated with sarcopenia by multivariate regression analysis.

The current study demonstrated that there was significant positive correlation between serum total testosterone and SMI $(\mathrm{r}=0.819, \mathrm{P}<0.001)$ in agreement with Sinclair et al. [3] who reported that muscle mass was positively associated with serum total testosterone levels (tau $0.13, \mathrm{P}=0.02$ ). Also we detected a significant positive correlation between serum total testosterone and hemoglobin concentration, serum albumin \& serum sodium in cirrhotic patients. These results were in agreement with those reported by Sinclair et al. [29] who detected a positive association between total testosterone and hemoglobin concentration $(\mathrm{P}<0.001)$, serum sodium and albumin. Exogenous testosterone administration increases erythropoiesis, and predispose to polycythaemia thus, this relationship could plausibly be a causal one [30].

We found significant positive correlation between serum total testosterone and platelets $(r=0.904$, $\mathrm{P}<0.001$ ). However Sinclair et al. [29] demonstrated non-significant correlations between total testosterone levels and platelet count. The 
present study revealed that, there was high significant negative correlation between total testosterone and MELD score ( $\mathrm{r}-0.928$, $\mathrm{P}<0.001)$, INR ( $\mathrm{r}-0.853, \mathrm{P}<0.001)$ \& Bilirubin ( $\mathrm{r}$ $-0.795, \mathrm{P}<0.001)$. This result agreed with Sinclair et al. [3] and Sinclair et al. [29].

We found that SMI positively correlated with serum $\mathrm{Na}$ (r 0.630, $\mathrm{P}<0.001)$ in agreement with Sinclair et al. [3] who found a positive correlation between muscle mass $\&$ serum sodium (tau 0.18 , $\mathrm{P}=0.002)$. Also we found a positive association between SMI and Serum albumin (r 0.681, $\mathrm{P}<0.001)$, and a significant negative correlation between SMI and MELD score ( $\mathrm{r}$-0.698, $\mathrm{P}<0.001)$. This result agreed with Sinclair et al., [3] who reported that (SMI) muscle mass negatively correlated with MELD score (tau $0.16, \mathrm{P}=0.007)$. On the other hand Montano loza et al [8] reported a poor correlation between sarcopenia and serum sodium $(\mathrm{r}=0.11, \mathrm{P}=0.2)$, serum albumin (r 0.02, $\mathrm{P}=0.9$ ) and MELD score $(r=0.04, P=0.7)$. This disagreement may be due to difference in L3 SMI cutoff used in diagnosis of sarcopenia, as they depend on L3 SMI, $\leq 52.4$ $\mathrm{cm} 2 / \mathrm{m} 2$ for men whatever their body mass index.

\section{CONCLUSION}

Our data demonstrated that serum levels of free and total testosterone were significantly lower in cirrhotic males than controls, with the lowest levels in child $\mathrm{C}$ cirrhotic patients. Additionally, serum testosterone level positively correlated with The L3 Skeletal Muscle Index (SMI) and the presence of sarcopenia in male patients with liver cirrhosis, with negative correlation with severity of liver cirrhosis as assessed by MELD score.

\section{Funding: None.}

\section{Conflicts of interest: None.}

Ethical approval: Approved

\section{REFERENCES}

1. Arroyo V, Moreau R, Kamath PS, Jalan R, Ginès $\mathrm{P}$, Nevens $\mathrm{F}$ et al. Acute-on-chronic liver failure in cirrhosis. Nat Rev Dis Primers, 2016; 2:16041.

2. Sorrell JH and Brown JR: Sexual functioning in patients with end-stage liver disease before and after transplantation. Liver Transpl, 2006; 12: 1473 - 1477.

3. Sinclair M, Grossmann M, Gow PJ and Angus PW: Testosterone in men with advanced liver disease: abnormalities and implications. $J$ Gastroenterol Hepatol, 2015; 30(2):244-51.
4. El Maghraoui A: Denutrition, cachexia and osteoporosis. Revue $d u$ Rhumatisme Monographies, 2013; 80:100-4.

5. Tandon P, Low G, Mourtzakis M, Zenith L, Myers RP, Abraldes JG et al. A Model to Identify Sarcopenia in Patients with Cirrhosis. Clin Gastroenterol Hepatol, 2016; 14(10):1473-1480.

6. Mehta SS and Fallon MB: Muscle cramps in liver disease. Clin Gastroenterol Hepatol, 2013; 11: 1385-91.

7. Prado CM, Lieffers JR, McCargar LJ, Reiman T, Sawyer MB, Martin L et al. Prevalence and clinical implications of sarcopenic obesity in patients with solid tumours of the respiratory and gastrointestinal tracts: a population-based study. Lancet Oncol, 2008; 9: 629-35 .

8. Montano-Loza AJ, Meza-Junco J, Prado CM, Lieffers JR, Baracos VE, Bain VG et al. Muscle wasting is associated with mortality in patients with cirrhosis. Clin Gastroenterol Hepatol, 2012; 10: $166-73,73$

9. Grossmann M, Hoermann R, Gani L, Chan I, Cheung A, Gow P et al. Low testosterone levels as an independent predictor of mortality in men with chronic liver disease. Clin. Endocrinol. (Oxf), 2012; 77: 323-8 .et al., 2012

10. Vermeulen A, Verdonck L and Kaufman JM: A critical evaluation of simple methods for the estimation of free testosterone in serum. J Clin Endocrinol Metab, 1999; 84(10):3666-72.

11. Bhasin S, Pencina M, Jasuja GK, Travison T, Coviello A, Orwoll E et al. Reference ranges for testosterone in men. J Clin Endocrinol Metab, 2011; 96(8):2430-9.

12. Lauretani F, Russo CR, Bandinelli S, Bartali B., Cavazzini C., Di Iorio A et al. Age-associated changes in skeletal muscles and their effect on mobility: an operational diagnosis of sarcopenia. Appl Physiol, 2003 Nov; 95(5):1851-60.

13. Martin L, Birdsell L, Macdonald N, Reiman T, Clandinin MT, Mc Cargar LJ et al. Cancer cachexia in the age of obesity: skeletal muscle depletion is a powerful prognostic factor, independent of body mass index. J Clin Oncol, 2013; 31(12):1539-47.

14. Lozano R, Naghavi M, Foreman K, Lim S, Shibuya K, Aboyans V, et al. Global and regional mortality from 235 causes of death for 20 age groups in 1990 and 2010: a systematic analysis for the Global Burden of Disease Study, 2010. Lancet, 2012; 380: 2095-128.

15. Sorrell JH and Brown JR: Sexual functioning in patients with end-stage liver disease before and after transplantation. Liver Transpl, 2006; 12: 1473 - 1477.

16. Grossmann M, Hoermann R, Gani L, Chan I, Cheung A, Gow PJ et al. Low testosterone levels as an independent predictor of mortality in men with chronic liver disease. Clin. Endocrinol. (Oxf), 2012; 77: 323-8. 
17. Zifroni A, Schiavi RC and Schaffner F: Sexual function and testosterone levels in men with nonalcoholic liver disease. Hepatology, 1991; 14: 479-82.

18. Yee HF and Lidofsky SD: Acute liver failure. In: Feldman M., Friedman L.S. and Sleisenger M.H (Eds.): Gastrointestinal and liver disease. Pathophysiology, Diagnosis and management, Saunders (Pub) Philadelphia. 3rd (Edn) 2002; PP: 1567:1574.

19. De Bruyn $G$ and Graviss E: A systematic review of the diagnostic accuracy of physical examination for the detection of cirrhosis. $B M E$. Med. Inform. Disease, 2001; 1(1):6

20. Yurci A, Yucesoy M, Unluhizarci K, Torun E, Gursoy S, Baskol M et al. Effects of testosterone gel treatment in hypogonadal men with liver cirrhosis. Clin Res Hepatol Gastroenterol, 2011; 35: 845-54.

21. Southren AL, Gordon GG, Olivo J, Rafii F and Rosenthal WS: Androgen metabolism in cirrhosis of liver. Metabolism, 1973; 22:695-701.

22. Scaglione S, Kliethermes S, Cao G, Shoham D, Durazo R, Luke A et al. The epidemiology of cirrhosis in the United States: a population-based study. J Clin Gastroenterol, 2015; 49:690-6.

23. Baumgartner RN, Koehler KM, Gallagher D, Romero L, Heymsfield SB, Ross RR et al. Epidemiology of sarcopenia among the elderly in New Mexico. Am J Epidemiol, 1998; 147(8):75563.

24. Krell RW, Kaul DR, Martin AR, Englesbe MJ, Sonnenday CJ, Cai $\mathrm{S}$ et al. Association between sarcopenia and the risk of serious infection among adults undergoing liver transplantation. Liver Transplant, 2013; 19: 1396-402.

25. Kim HY and Jang JW: Sarcopenia in the prognosis of cirrhosis: Going beyond the MELD score. World J Gastroenterol, 2012; 21(25):763747.

26. Garcia PS, Cabbabe A, Kambadur R, Nicholas G and Csete M: Brief-reports: elevated myostatin levels in patients with liver disease: a potential contributor to skeletal muscle wasting. Anesthesia and Analgesia, 2010; 111(3):707-9.

27 Tsien C, Davuluri G, Singh D, Allawy A, Ten Have GA, Thapaliya $S$ al. Metabolic and molecular responses to leucine-enriched branched chain amino acid supplementation in the skeletal muscle of alcoholic cirrhosis. Hepatology, 2015; 61(6):2018-29.

28 Tandon, P, Low G, Mourtzakis M, Ma MM, Burak KW, Montano-Loza AJ et al. P0128 Low Testosterone Levels Are Associated with Sarcopenia in Cirrhotic Patients. Journal of Hepatology, 2015; 62: n. pag. Web.

29 Sinclair S, Grossmann M, Angus PW, Hoermann $\mathrm{R}$, Hey $\mathrm{P}$, Scodellaro $\mathrm{T}$ et al. Low testosterone as a better predictor of mortality than sarcopenia in men with advanced liver disease. J Gastroenterol Hepatol, 2016; 31(3):661-7.

30 Maggio M, Snyder PJ, Ceda GP, Milaneschi Y, Luci M, Cattabiani C et al. Is the haematopoietic effect of testosterone mediated by erythropoietin? The results of a clinical trial in older men. Andrology, 2013; 1:24-8. 